Research Article

\title{
In Vitro Cultivation of Aphelenchoides besseyi Christie on Fungal Cultures
}

\author{
Annisa Nur Imamah ${ }^{1)}$, Supramana ${ }^{1) *}$, \& Tri Asmira Damayanti ${ }^{1)}$ \\ ${ }^{1)}$ Department of Plant Protection, Faculty of Agriculture, IPB University \\ IPB Dramaga, Bogor, West Java, 16680 Indonesia \\ *Corresponding author.E-mail: supramana@ipb.ac.id
}

\begin{abstract}
White tip disease on rice caused by Aphelenchoides besseyi is categorized as emerging infectious disease in Indonesia because the disease incidence and its geographical distributionare increasing rapidly. Until presently, there is no information related with mass culture technique of Ap. besseyi in Indonesia. Thus, studies to obtain pure population of Ap. besseyi are necessary to be conducted to support various research aspects in the future. This research is aimed to study $A p$. besseyi pure mass culture technique by rearing the nematode on three fungal species. Three different fungal cultures on PDA medium, i.e. Alternaria padwickii, Fusarium semitectum, and Botrytis cinerea were tested as Ap. besseyi cultivation media. To obtain the optimum condition for nematode cultivation, the fungal cultures were incubated in three different temperature. The nematodes were surface sterilized with $0.1 \%$ streptomycin sulfate followed by washing with sterilized water before infesting the nematode into fungal culture. Subsequently, 25 sterilized nematodes were infested into 7 days old of fungal culture and incubated at $20^{\circ} \mathrm{C}, 25^{\circ} \mathrm{C}$ and $30^{\circ} \mathrm{C}$. After 21 days, nematodes were harvested and counted the final population. Among fungal species tested as rearing medium, the best culture for Ap. besseyi reproduction was on $\mathrm{Al}$. padwickii culture at $25^{\circ} \mathrm{C}$ with average final population up to 9,115 per petri dish and reproduction factor 364.6 . At a $30^{\circ} \mathrm{C}, A p$. besseyi was failed to develop its population in all the fungal cultures tested. It indicated that the optimum temperature for reproduction of $A p$. besseyi on those of fungal species was $20-25^{\circ} \mathrm{C}$.
\end{abstract}

Keywords: Aphelenchoides besseyi; in vitro culture nematode; reproduction factor; temperature

\section{INTRODUCTION}

Aphelenchoides is a genus that is consisted of parasitic nematodes on high-level plants, associated with insects, and most species are microphagous nematodes. Some Aphelenchoides species recognized as major pests include Aphelenchoides besseyi Christie, Ap. ritzemabosi (Schwartz) Steiner and Buhrer, Ap. fragariae (Ritzema Bos) Christie and Ap. arachidis Bos. (De Waele, 2002). Ap. besseyi are recognized to cause white tips on rice and are distributed in rice fields around the globe (EPPO, 2017).

White tips were first found in Indonesia in 2014 and caused a distinctive symptom of the ends of rice leaves to turn white (Wiyono et al., 2017). In Java, Ap. besseyi have been reported at Banten (Lebak), West Java (Bogor, Sukabumi, Subang, and Indramayu), Central Java (Klaten, Sragen, Sukoharjo, Boyolali, Pati, and Pemalang), Special Region of Yogyakarta (Yogyakarta and Sleman), East Java (Magetan, Blitar, Tuban, Gresik, Nganjuk, and Banyuwangi) (Diana, 2018).
Ap. besseyi is an ectoparasite and seedborne nematode. Nematodes have been reported to be found on seed glumes. Dormant nematodes will re-establish when preferred humidity levels are reached. Nematodes move through water on plant surfaces and migrate to leaves and stem growing points to obtain nutrients. Optimum temperature for the development of this nematode is approximately $21-25^{\circ} \mathrm{C}$ and nematodes have been reported to survive in dry condition for 2-3 years (Hockland, 2004).

Besides infecting high-level plants, this nematode also feed on fungi. Ap. besseyi mass rearing on fungal species may serve as an efficient method to obtain high populations of pure nematodes, which will support further research of this species. Fungal species known to support growth for Ap. besseyi in vitro rearing include Fusarium solani (Huang et al., 1972), Aerobasidium pullulans (Huang et al., 1979), Alternaria tenuis (Todd \& Atkins, 1958), and Botrytis cinerea. In addition, fungal cultures known as the best fungi for Ap. besseyi include Alternaria alternata, Fusarium moniliforme, Phoma medicaginis, F. solani, 
F. equiseti (Gokte \& Mathur, 1989), Bipolaris oryzae and Magnaporthe salvini (Jamali et al., 2008).

Ap. besseyi are able to reproduce parthenogenically or amphimictically. Parthenogenesis is an asexual reproduction where female nematodes produce eggs cells without fertilization. This behavior causes nematodes to be able to produce many offspring. However, competition to obtain nutrient also increases. Amphimictic is a sexual reproduction where sperm and egg cells from different individuals meet (cross fertilization). Nematodes are able to mate freely and produce fertile offspring. Population of Ap. besseyi from Russia were able to parthenogenesis on Fusarium solani cultures (Sudakova \& Stoyakov, 1967), while Ap. besseyi populations from Taiwan were able to reproduce amphimictically on Aerobasidium pullulans cultures (Huang et al., 1979). To our knowledge, until today there has not been scientific information on mass rearing of Ap. besseyi populations from Indonesia on fungal culture mediums. Mass rearing techniques for Ap.besseyi is essential for further research. Therefore, this study aims to investigate fungal species medium and temperature combinations for optimum Ap. besseyi rearing.

\section{MATERIAL AND METHODS}

\section{Ap. besseyi and Fungal Culture}

Ap. besseyi used in the study were collected from rice seeds, variety Pak Tiwi-1, and obtained from Balai Besar Padi Sukamandi Subang. Nematode extraction was done using the Baermann funnel method based on procedures from International Seed Testing Association (ISTA) (2018), by cutting $5 \mathrm{~g}$ of seed hilum. After cutting hilum, seeds were placed on cloths and immersed in water. Incubation was done for 24 hours at $25^{\circ} \mathrm{C}$. Incubation results were extracted using a 500 mesh. Ap. besseyi surfaces were sterilized using streptomycin sulphate $(0.1 \%)$ for 10 minutes followed by rinsing wth sterilized water for 3 times. Fungal species used as rearing medium of Ap. besseyi were Alternaria padwickii, Fusarium semitectum, and Botrytis cinerea. Cultures were obtained from the Mycology Laboratory, Faculty of Agriculture, Bogor Agriculture Institute. Fungal colonies were grown on Potato Dextrose Agar (PDA) medium on 9-cm petri dishes. Fungal cultures were incubated at $25^{\circ} \mathrm{C}$ and grown until entire surfaces of medium were covered with mycelium.

\section{Ap. besseyi rearing on Fungal Cultures}

Twenty five nematodes were infested to each petri dish when mycelium of tested fungal species has entirely covered the medium. Each petri dish was stored in a black plastic bags and incubated in dark conditions at temperatures of $20^{\circ} \mathrm{C}, 25^{\circ} \mathrm{C}$, and $30^{\circ} \mathrm{C}$. Nematodes were harvested 21 days after infestation, followed by population counts. Mediums were sliced and extracted using a modified Baermann funnel method. Numbers of juvenile and mature nematodes were calculated using the formula from Coyne et al. (2014):

$$
\mathrm{N}=\frac{\mathrm{V}}{\mathrm{V}} \times \mathrm{n}
$$

$\mathrm{N}=$ nematode population

$\mathrm{V}=$ suspension volume in bottle

$\mathrm{v}=$ suspension volume in syracuse dish

$\mathrm{n}=$ average number counted under microscope

Total number of juvenile and mature nematodes were used as final population densities. Reproduction factor (FR) was calculated accordance to the formula used by Jamali et al. (2008):

$$
\mathrm{FR}=\frac{\mathrm{Pf}}{\mathrm{Pi}}
$$

$\mathrm{Pf}=$ final nematode population

$\mathrm{Pi}=$ beginning nematode population

\section{Experimental Design and Data Analysis}

This study was designed as a Factorial Complete Randomized Design. The first factor were the three fungal species used as medium and the second factors were the three incubation temperatures Treatment combination tested were nine and each treatment combination consisted of nine replications. Data obtained were processed using Excel 2013 and analyzed using Minitab 16 Statistical Software with a Tukey post-hoc test at $95 \%$ confidence level.

\section{RESULTS AND DISCUSSION}

Fungal species used as rearing medium of $A p$. besseyi are all considered as plant pathogens. $A l$. padwickii and $F$. semitectum are pathogen that infect rice seeds in the fields and storages, while $B$. cinerea is a pathogen on strawberries which causes grey mold. Colony of Al. padwickii on PDA medium were gray with smooth mycelium. Colony located 
on the underside of the PDA medium was black. Conidiophores were dark colored, elongated, and conidia contained 7-8 septas that were oval shaped. Macromorphological characteristics of $F$. semitectum on PDA mediums contained dense mycelium and was white to brownish depending on its age. Abundant microconidia were oval shaped, in general contained three septas, hypha microscopically were transparent and possessed septas. Colonies of $B$. cinerea on PDA medium were greyish brown with white cotton-like mycelium on the edges. Conidiophores were long, slim, contained hyaline, irregularly branched on top, and apical cells were larger and round (Figure 1).

Rearing of Ap. besseyi resulted in various growth stages of nematodes, including juvenile to mature nematodes (Figure 2). Female nematodes were elongated, with lengths of $0.66-0.75 \mathrm{~mm}$ and slender. Mouths were round, did not contained striations and in general were wider than their neck or parallel with their body width. Heads were flat and round on its anterior with a strong and sclerotized supporting structure, which forms the head structure and function to point their thin and slightly offset stylets. Cuticles were smooth annulation. Sizes and shapes of male nematodes were similar to females, except for the characteristics of their reproduction structure.

Results of Ap. besseyi rearing on three culture species showed that nematode population varied between culture species and incubation temperature. Population of Ap. besseyi reached the highest number, 9,115 individuals, when reared on Al. padwickii at $25^{\circ} \mathrm{C}$, while the lowest population were obtained from nematodes reared on $B$. cinerea at $30^{\circ} \mathrm{C}$ (Table 1). Optimum temperature for Ap. besseyi development is $21-25^{\circ} \mathrm{C}$, their life cycles last for about 10 days at $21^{\circ} \mathrm{C}$, eight days at $23^{\circ} \mathrm{C}$, and nematode did not grow at $13^{\circ} \mathrm{C}$ (Bridge et al., 2005).

On fungal mediums, Ap. besseyi have been reported to be able to finish their life cycle at $20^{\circ} \mathrm{C}$ (Rajan et al., 1990) and between $23-30^{\circ} \mathrm{C}$ (Huang et al., 1972). Research have shown that temperature affect $A p$. besseyi development. At incubation temperatures of $20^{\circ} \mathrm{C}$ and $25^{\circ} \mathrm{C}, A p$. besseyi populations inoculated on Al. padwickii and F. semitectum showed higher populations compared with nematodes incubated at $30^{\circ} \mathrm{C}$. Temperatures between 20 to $25^{\circ} \mathrm{C}$ were the most suitable conditions for Ap. besseyi development. Although oviposition, molting, and egg hatching still occurred at $30^{\circ} \mathrm{C}, A p$. besseyi were not able to development well. Nurjanah et al. (2016) stated that

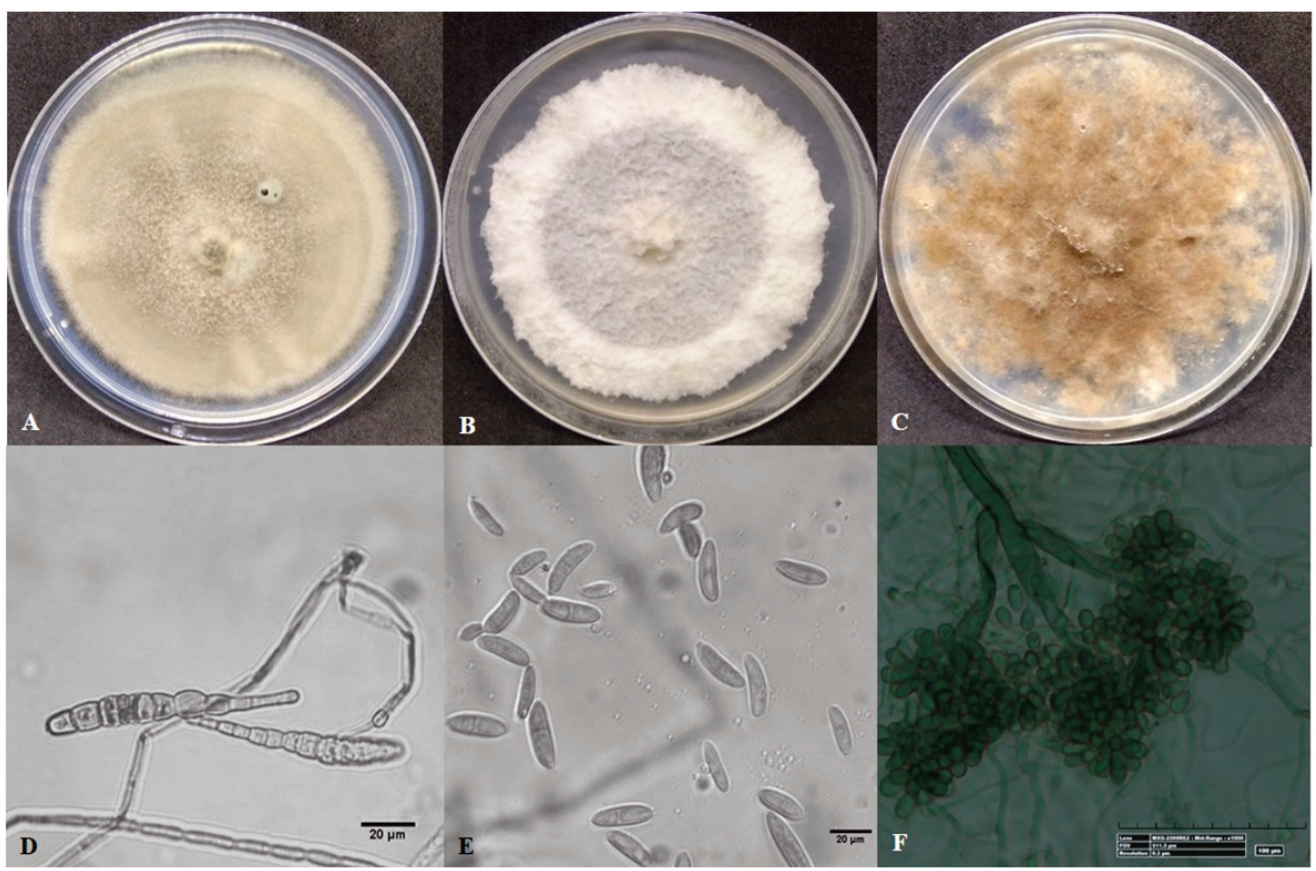

Figure 1. Fungal cultures and microscopic appearances of species used as rearing mediums of Aphelenchoides besseyi; Alternaria padwickii (A, D), Fusarium semitectum (B, E), Botrytis cinerea (C, F) 


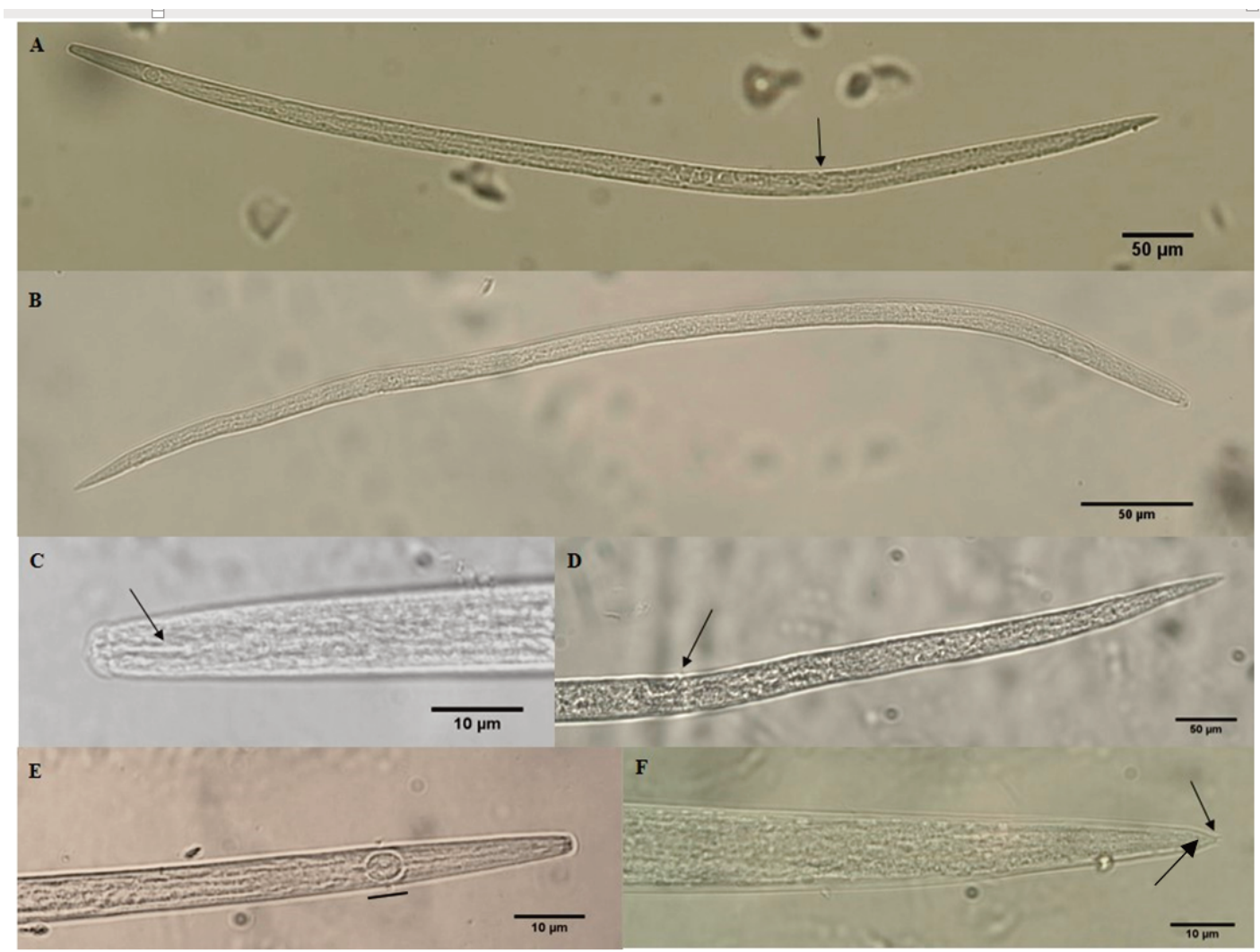

Figure 2. Aphelenchoides besseyi morphology from nematodes reared on fungal cultures: (A) mature nematode, (B) juvenile nematode, (C) stylet, (D) vulva, (E) metacorpus, (F) mucron

Table 1. Population and reproduction factor of Aphelenchoides besseyi on different fungal cultures and temperatures

\begin{tabular}{|c|c|c|c|c|c|}
\hline \multirow{2}{*}{ Fungal Species } & \multirow{2}{*}{$\begin{array}{c}\text { Incubation } \\
\text { Temperature } \\
\left({ }^{\circ} \mathrm{C}\right)\end{array}$} & \multicolumn{4}{|c|}{ Individuals } \\
\hline & & ${ }^{\mathrm{a}}$ Juvenile & ${ }^{\mathrm{a}}$ Mature & ${ }^{\mathrm{a}}$ Total & ${ }^{\mathrm{a}} \mathrm{RF}$ \\
\hline AP & & $2,236 \pm 0.38 a$ & $3,887 \pm 0.34 \mathrm{a}$ & $6,123 \pm 0,32 a$ & $244.9 \pm 0.32 \mathrm{a}$ \\
\hline FS & 20 & $1,016 \pm 0.29 a$ & $1,817 \pm 0.29 a$ & $2,833 \pm 0,28 \mathrm{a}$ & $113.3 \pm 0.27 \mathrm{a}$ \\
\hline $\mathrm{BC}$ & & $99 \pm 0.8 b$ & $159 \pm 0.86 b$ & $259 \pm 0,89 b$ & $10.3 \pm 0.53 b$ \\
\hline AP & & $2,206 \pm 0.95 a$ & $6,909 \pm 0.25 \mathrm{a}$ & $9,115 \pm 0,3 a$ & $364.6 \pm 0.3 a$ \\
\hline FS & 25 & $1,588 \pm 0.18 \mathrm{a}$ & $4,747 \pm 0.35 \mathrm{a}$ & $6,335 \pm 0,29 a$ & $253.4 \pm 0.29 a$ \\
\hline $\mathrm{BC}$ & & $37 \pm 0.89 b c$ & $100 \pm 1.15 b$ & $137 \pm 1,13 b c$ & $5.5 \pm 0.55 b c$ \\
\hline AP & & $7 \pm 0.62 c$ & $59 \pm 0.4 b$ & $65 \pm 0,42 b c$ & $2.6 \pm 0.25 b c$ \\
\hline FS & 30 & $24 \pm 0.87 b c$ & $134 \pm 0.65 b$ & $158 \pm 0,69 b c$ & $6.3 \pm 0.49 b c$ \\
\hline $\mathrm{BC}$ & & $4 \pm 0.53 c$ & $17 \pm 0.71 b$ & $21 \pm 0,75 c$ & $0.8 \pm 0.21 \mathrm{c}$ \\
\hline
\end{tabular}

Information: $\mathrm{AP}=$ Alternaria padwickii, $\mathrm{FS}=$ Fusarium semitectum, $\mathrm{BC}=$ Botrytis cinerea, $\mathrm{RF}=$ Reproduction Factor;

${ }^{\mathrm{a}}$ Numbers followed by different letters in the same column are not significantly different (Tukey post-hoc test $\alpha=0.05$ )

the effects of temperature on embryo development is one the main factor that affect nematode ecology and distribution.

Reproduction factor of Ap. besseyi was the highest on $\mathrm{Al}$. padwickii and F. semitectum incubated at $25^{\circ} \mathrm{C}$ and $\mathrm{Al}$. padwickii at $20^{\circ} \mathrm{C}$. Reproduction factor of Ap. besseyi reared on Al. padwickii incubated at $25^{\circ} \mathrm{C}$ reached 364.6 times implying that $A p$. besseyi were able to complete their life cycle and reproduce.
However, when reared on $B$. cinerea at $25^{\circ} \mathrm{C}$, reproduction factor only reached 5.5 times. Reproduction factor of nematodes reared on $B$. cinerea at $25^{\circ} \mathrm{C}$ was lower compared to nematodes reared on $F$. semitectum incubated at $30^{\circ} \mathrm{C}$, specifically 6.3 times. This implies that Ap. besseyi were still able to survive and reproduce on $F$. semitectum at $30^{\circ} \mathrm{C}$ even though conditions were not optimum (Table 1). 
Food source is an important factor that determines the increase of nematode populations. Food preferences of Ap. besseyi can be evaluated based on the population of mature nematodes from different fungi cultures. Several fungal species have essential function and can be considered to increase Ap. besseyi reproduction in vitro (Rajan et al., 1990; Jamali et al., 2008). The highest Ap. besseyi population was obtained from Al. padwickii grown on PDA mediums incubated at $25^{\circ} \mathrm{C}$. PDA was the best substrate for growing fungi used for $A p$. besseyi rearing. Nematodes prefer mycelium rather than conidia as food source. Therefore, nematodes are not able to reproduce and survive on medium that induct fungi sporulation (Jamali et al., 2008).

At $25^{\circ} \mathrm{C}$, reproduction factor of nematodes reared on Al. padwickii was 364.6 times, while $F$. semitectum was 253.4 times. Therefore, Al. padwickii grown on PDA and incubated at $25^{\circ} \mathrm{C}$ may be an alternative to rear Ap. besseyi in laboratories for ecological, epidemiological, and molecular testing. However, Al. padwickii grows slower than $F$. semitectum causing longer time for preparation before being able to be inoculated with Ap. besseyi.

\section{CONCLUSION}

All three fungal species were suitable as mass rearing media for Ap. besseyi with population density depending on the combination of fungal species and temperature. Between all fungal species and temperature combinations, Al. padwicki inoculated at $25^{\circ} \mathrm{C}$ was the best combination for Ap. besseyi mass rearing.

\section{LITERATURE CITED}

Bridge, J., R.A. Plowright, \& D. Peng. 2005. Nematode Parasites of Rice., p. 133-176. In M. Luc, R.A. Sikora, \& J. Bridge (eds.), Plant Parasitic Nematodes in Subtropical and Tropical Agriculture. CABI, Wallingford.

Coyne, D., J.M. Nicol, \& B. Claudius-Cole. 2014. Practical Plant Nematology: A Field and Laboratory Guide. $2^{\text {nd }}$ Ed. SP-IPM Secretariat, International Institute of Tropical Agriculture (IITA), Cotonou, Benin.

De Waele, D. 2002. Foliar Nematodes: Aphelenchoides besseyi. p. 141-151. In J.L. Starr, J. Bridge, \& R. Cook (eds.), Resistance to Plant-Parasitic Nematodes: History, Current Use and Future Potential. CABI Publishing, Wallingford.
Diana, D.R. 2018. Distribusi Nematoda Pucuk Putih Padi Aphelenchoides besseyi di Pulau Jawa. Jurnal Fitopatologi Indonesia 14: 129-137.

[EPPO] European Plant Protection Organization. 2017. PM 7/39 (2) Aphelenchoides besseyi. EPPO Bulletin 47: 384-400.

Gokte, N. \& V. Mathur. 1989. Reproduction and Development of Aphelenchoides besseyi. Phytoparasitica 17: 263-267.

Hockland, S. 2004. Aphelenchoides besseyi. EPPO Bulletin. 34: 303-308.

Huang, C., S. Huang, \& Y. Chiang. 1979. Mode of Reproduction and Sex Ratio of Rice White-tip Nematode, Aphelenchoides besseyi. Nematologica 25: 255-260.

Huang, C., S. Huang \& L. Lin. 1972. The Effect of Temperature on Development and Generation Periods of Aphelenchoides besseyi. Nematologica 18: 432-438.

[ISTA] International Seed Testing Association. 2018. International Rules for Seed Testing. Annexe to Chapter 2: sampling: i-2-44. ISTA, Bassersdorf

Jamali, S., E. Pourjam, A. Alizadeh, \& F. Alinia. 2008. Reproduction of the White tip Nematode (Aphelenchoides besseyi Christie, 1942) in Different Monoxenic Cultures. Journal of Agricultural Science and Technology 10: 165-171.

Nurjanah, N., Trisyono, S. Indarti, \& S. Hartono. 2016. The Effect of Temperature, Potato Varieties, and the Origin of Cyst on the Reproductive Biology of Globodera rostochiensis. Jurnal Perlindungan Tanaman Indonesia 20: 84-88.

Rajan, A. Lal, \& V. Mathur. 1990. Host Range and Morphological Studies on Four Isolates of Aphelenchoides besseyi Christie. Indian Journal of Nematology 20: 177-183.

Sudakova, M. \& A. Stoyakov. 1967. Reproduction and Duration of Life of Aphelenchoides besseyi Christie, 1942. Zoologicheskii Zhurnal 46: 10791099.

Todd, E. \& J. Atkins. 1958. White-tip Disease of Rice. 1. Symptoms, Laboratory Culture of Nematodes, and Pathogenicity Tests. Phytopathology 48: 632-637.

Wiyono, S., Giyanto, K.H. Mutaqin, S.H. Hidayat, Supramana, \& Widodo. 2017. Emerging Disease pada Tanaman Pertanian: Strategi Pengendalian dan Opsi Kebijakan, p. 1-11, In S.H. Hidayat, A. Priyatmojo, S. Wiyono, Giyanto, Supramana, B. Istiaji (eds.), Simposium Nasional Fitopatologi Kemunculan Penyakit Baru dan Impor Benih. Unit Kajian Pengendalian Hama Terpadu, Fakultas Pertanian, IPB, Bogor, January 10, 2017. 